\title{
An in Vivo-in Vitro Alkaline DNA Unwinding Assay for Hepatic DNA Damage: Comparison with the Alkaline Sucrose Gradient Centrifugation Technique ${ }^{1}$
}

\author{
RICHARD D. STORER ${ }^{2,3}$ AND RORY B. CONOLLY \\ Toxicology Research Laboratory, Department of Environmental and Industrial Health, School of Public Health, \\ The University of Michigan, Ann Arbor, Michigan 48109-2029 \\ Received January 16, 1984

\begin{abstract}
An in vivo-in vitro alkaline DNA unwinding assay for single-strand breaks and/or alkalilabile lesions in hepatic DNA is described. The assay involves isolation of hepatic nuclei from mice, alkaline denaturation and unwinding of hepatic DNA, separation of single- and doublestranded DNA by hydroxylapatite batch chromatography, and quantitation of DNA in chromatographic fractions by a fluorometric assay. The method allows for the sensitive detection of hepatic DNA damage following in vivo administration of xenobiotics. Using this procedure, DNA fragmentation was demonstrated in alkali after administration of as little as $0.5 \mathrm{mg} / \mathrm{kg}$ of $N$-nitrosodimethylamine (DMN) to male $\mathrm{B} 6 \mathrm{C} 3 \mathrm{~F} 1$ mice. A comparison of this technique with a similar alkaline sucrose density gradient centrifugation assay demonstrated comparable limits of sensitivity for the two procedures. (C) 1984 Academic Press, Inc.
\end{abstract} \\ KEY WORDS: alkaline DNA unwinding; hepatic DNA damage.
}

The development of sensitive, short-term tests for the assessment of the carcinogenic and mutagenic potential of chemicals continues to be a productive area of research in chemical carcinogenesis and toxicology. Techniques for the measurement of primary DNA damage in mammalian cells have proved particularly valuable in this area. The effects detected, such as unscheduled DNA synthesis (1-3) and DNA strand breakage (4-8), have been shown to be well correlated with the carcinogenic and/or mutagenic potentials of compounds tested $(9,10)$. In addition, the development and application of these test systems to tissues from animals treated in vivo have allowed for the study of the organotropic effects of different compounds in the whole animal $(1,11-16)$. Whereas these systems inherently account

\footnotetext{
${ }^{1}$ Supported by NIH grant 5 T32 ES07062.

${ }^{2}$ Present address: Merck Institute for Therapeutic Research, Merck Sharp and Dohme Research Laboratories, Building 44-1, West Point, Pa. 19486.

${ }^{3}$ To whom correspondence should be addressed.
}

for the pharmacokinetics of the test compound and the metabolic activation and detoxification capabilities of the target tissue, they are considered valuable new tools with which to assess the genotoxic potential of chemicals.

In this communication, we describe a sensitive, in vivo-in vitro alkaline DNA unwinding assay for the detection of single-strand breaks and alkali-labile lesions in hepatic DNA from animals treated with genotoxic compounds. The assay is based on the timedependent alkaline denaturation and unwinding of DNA $(17,18)$. Single-strand breaks in alkali-treated DNA, which increase the amount of single-stranded DNA formed in alkali during the brief period allowed for unwinding, are then detected as a decrease in the fraction of the DNA rccovered as double-stranded DNA after hydroxylapatite batch chromatography (19). The technique is rapid and sensitive, and allows for the concurrent analysis of tissue samples from a large number of animals. Using this method, 
we have investigated the effects of low (0.25$2.5 \mathrm{mg} / \mathrm{kg}$ ) doses of $N$-nitrosodimethylamine $(\mathrm{DMN})^{4}$ on the hepatic DNA from male mice and compared these effects with those seen in an in vivo-in vitro alkaline sucrose density gradient centrifugation assay.

\section{MATERIALS AND METHODS}

Animals. Male B6C3F1 mice were purchased from the Charles River Breeding Laboratories (Portage, Mich.) or bred in our laboratory from $\mathrm{C} 3 \mathrm{H}$ male and $\mathrm{C} 57 \mathrm{BL}$ female mice obtained from the Charles River Breeding Laboratories (Portage, Mich.). Animals were 6-9 weeks of age at the time of experiments. Mice were housed eight to ten per cage, bedded in soft wood chips, and fed Purina rodent chow and water ad libitum until the morning of the experiments. Animal rooms were maintained at $22-24^{\circ} \mathrm{C}$ with a 12-hour light/dark cycle.

Chemicals and treatments. DMN was obtained from Sigma Chemical Company (St. Louis, Mo.) and was administered to the mice intraperitoneally in 0.1 to $0.3 \mathrm{ml}$ of $0.85 \% \mathrm{NaCl}$. 1,2-Dichloroethane (DCE) was obtained from MCB Organic Chemicals (Cincinnati, Ohio) and was administered ip in corn oil in a constant volume of $5 \mathrm{ml} / \mathrm{kg}$. The purity of the DCE was checked by gas chromatography and found to be greater than $99.9 \%$ Diaminobenzoic acid dihydrochloride was obtained from Aldrich Chemicals (Milwaukee, Wisc.). Hydroxylapatite (Bio-Gel HTP, DNA grade) was purchased from Bio-Rad Laboratories (Richmond, Calif.).

Isolation of hepatic nuclei. A suspension of hepatic nuclei was prepared as described by Cox et al. (11), with minor modifications. Briefly, mice were sacrificed by cervical dislocation and their livers removed and squashed gently in $3.0 \mathrm{ml}$ of cold $0.075 \mathrm{M}$ $\mathrm{NaCl}, 0.024 \mathrm{M}$ EDTA-Na, $\mathrm{pH}$ 7.5. The

\footnotetext{
${ }^{4}$ Abbreviations used: DMN, $N$-nitrosodimethylamine; DCE, 1,2-dichloroethane; UDS, unscheduled DNA synthesis.
}

resulting suspension of tissue fragments, whole cells, and nuclei was then centrifuged for $1 \mathrm{~min}$ at $42 \mathrm{~g}$ at $4^{\circ} \mathrm{C}$. The supernatant containing isolated nuclei and occasional whole cells was transferred to a separate tube and the nuclei were counted in a hemocytometer. The concentration of nuclei was then adjusted to $5 \times 10^{6}$ nuclei $/ \mathrm{ml}$. Nuclei samples were kept on ice prior to alkaline lysis and denaturation.

Alkaline DNA unwinding. Alkaline denaturation and unwinding of hepatic DNA was carried out according to the procedure described by Rydberg (18), with several modifications. Fifty microliters of the ice-cold nuclei suspension $\left(2.5 \times 10^{5}\right.$ nuclei $)$ was injected into vials containing $1 \mathrm{ml}$ of an alkaline lysis solution at room temperature consisting of $0.3 \mathrm{M} \mathrm{NaCl}, 0.03 \mathrm{M}$ EDTA-Na, $0.1 \mathrm{M}$ Tris, and $0.2 \%$ sodium dodecyl sulfate, $\mathrm{pH}$ 12.5 , adjusted with $5.0 \mathrm{~N} \mathrm{NaOH}$ (11). After lysis and unwinding in the dark at $22-23^{\circ} \mathrm{C}$ for 40 minutes, DNA unwinding was terminated by rapid injection of $1.0 \mathrm{ml} 0.155 \mathrm{~N}$ $\mathrm{HCl}$ to neutralize the lysate to $\mathrm{pH} 7.0$. The samples were immediately (within 5 s) sonicated for $15 \mathrm{~s}$ (Branson 200 cell disrupter with microtip, setting 7) to reduce the molecular weight of the DNA and to inhibit reassociation of complementary strands. Finally, $680 \mu \mathrm{l}$ of $2.0 \%$ sodium lauroyl sarcosine in $0.2 \mathrm{M}$ EDTA- $\mathrm{Na}_{2}, \mathrm{pH} 7.0$, was added to the vials. For the determination of the kinetics of DNA unwinding, the lysis and unwinding period was varied from 10 to $60 \mathrm{~min}$.

Hydroxylapatite batch chromatography. Separation of single- and double-stranded DNA in neutralized lysates was accomplished by hydroxylapatite batch chromatography as described by Kanter and Schwartz (19). The amount of hydroxylapatite used was $0.25 \mathrm{~g}$ per tube and the elution volume was $2.5 \mathrm{ml}$. Single- and double-stranded DNA standards were prepared with each assay. Doublestranded DNA standards were prepared by pipetting $50 \mu \mathrm{l}$ of nuclei suspension into 1.0 $\mathrm{ml}$ of lysis solution which had already been neutralized with $1.0 \mathrm{ml}$ of $0.155 \mathrm{M} \mathrm{HCl}$. 
Single-stranded DNA standards were prepared by vortexing the samples vigorously 1 min after pipetting the nuclei into the lysis solution and allowing unwinding to proceed for $40 \mathrm{~min}$.

The DNA content of the chromatographic fractions was assayed by a modification of the technique described by Zubroff and Sarma (20). One hundred fifty microliters of bovine serum albumin $(2 \mathrm{mg} / \mathrm{ml})$ was added to 1.0 $\mathrm{ml}$ aliquots of each fraction followed by 1.0 $\mathrm{ml}$ of $40 \%$ trichloroacetic acid. The tubes were kept at $4^{\circ} \mathrm{C}$ overnight to precipitate DNA and then centrifuged at $3500 \mathrm{~g}$ for 15 $\min$ at $4^{\circ} \mathrm{C}$. Supernatants were aspirated and the precipitates resuspended and centrifuged twice, once with $0.5 \mathrm{ml}$ of $0.1 \mathrm{M}$ potassium acetate in ethanol and once with $1.0 \mathrm{ml}$ of absolute ethanol. Precipitates were then dried for $1 \mathrm{~h}$ at $60^{\circ} \mathrm{C}$. The DNA content of the precipitates was analyzed by the fluorometric method of Kissane and Robbins (21). Fifty microliters of a $400 \mathrm{mg} / \mathrm{ml}$ solution of diaminobenzoic acid dihydrochloride was added to each tube and the capped tubes were heated for $45 \mathrm{~min}$ at $60^{\circ} \mathrm{C}$. After the tubes were cooled, $0.65 \mathrm{ml}$ of $1.0 \mathrm{~N} \mathrm{HCl}$ was added to each tube and the relative fluorescent intensity read in a Perkin-Elmer Model 65040 spectrofluorometer at an excitation wavelength of $409 \mathrm{~nm}$ and an emission wavelength of $505 \mathrm{~nm}$. Results are expressed as the percentage of the total DNA which eluted from the hydroxylapatite as double-stranded DNA.

Alkaline sucrose gradients. Alkaline sucrose density gradient centrifugation was performed as previously described $(11,20)$ with minor modifications. Five-milliliter linear, 5-20\% alkaline sucrose gradients containing $0.9 \mathrm{M}$ $\mathrm{NaCl}$ and $0.3 \mathrm{M} \mathrm{NaOH}$ were prepared in cellulose nitrate tubes over a $1-\mathrm{ml}$ shelf of $2.3 \mathrm{M}$ sucrose. Three hundred microliters of alkaline lysis solution, prepared as described for alkaline DNA unwinding, was then layered on top of the gradient. An aliquot of hepatic nuclei suspension containing 1-2 $\times 10^{5}$ nuclei in $10-25 \mu \mathrm{l}$ was then injected carefully into the lysis layer, an additional
$0.1 \mathrm{ml}$ of lysis solution was added, and the tubes were filled with paraffin oil. (The concentration of sodium dodecyl sulfate in the lysis solution was varied from 0.2 to $0.5 \%$, in proportion to the number of nuclei used, to prevent precipitation of excess detergent in the alkaline sucrose.) After a 30 or $40 \mathrm{~min}$ lysis period as indicated under Results, tubes were centrifuged for $30 \mathrm{~min}$ at $25,500 \mathrm{rpm}$ in a Beckman SW 41 rotor in a Beckman $\mathrm{L} 5-75$ ultracentrifuge at $20^{\circ} \mathrm{C}$. Twelve to sixteen fractions were then collected from the bottom of the tubes by pumping paraffin oil onto the top. As the DNA in the control peak is of high molecular weight and very viscous, reproducible DNA recovery is best achieved if drops are collected directly from the bottom of pierced tubes without intervening collection needles and tubing. Precipitation and washing of DNA in gradient fractions were carried out as previously described (20), and the DNA content of each fraction was determined by the fluorometric method described above for the hydroxylapatite chromatography fractions.

Statistical analysis. Significance testing was by one-way analysis of variance (22) with multiple comparisons by the Bonferroni method (23). A value of $p \leqslant 0.05$ was considered to be significant.

\section{RESULTS}

Rydberg (18) proposed a model to describe the kinetics of DNA strand separation in alkali when breaks are induced at random along the DNA molecules. According to this model, DNA strand unwinding is initiated independently at each break or strand terminus along the DNA molecule and proceeds rapidly until the viscous drag on the rotating single-strand portion becomes rate limiting. The equation derived by Rydberg to describe the kinetics of the model is

$$
\ln F=-\left(C / M_{n}\right) \cdot t^{\beta},
$$

where $F$ is the fraction of the total DNA remaining double stranded after alkali treat- 
ment for time $t, C$ is a constant for the hydrodynamic friction coefficient for rotation, and $\beta$ is a constant which is dependent on the conformation of the DNA. $M_{n}$ is the number-average molecular weight of the DNA between two break points. When this model was tested cmpirically using an in vitro alkaline DNA unwinding assay for the effects of ionizing radiation on mammalian DNA, equation [1] appeared to describe the kinetics of unwinding quite well (18).

In the present study, the adequacy of this model in describing the kinetics of DNA unwinding after chemically induced damage to hepatic DNA was investigated. DNA adduct formation after treatment with alkylating agents is known to result in the formation of alkali-labile apurinic sites or alkali-labile phosphotriesters in DNA $(5,24)$. Since one of the simplifying assumptions in Rydberg's model is that DNA lesions other than in situ strand breaks will not affect the rate of strand separation or be labile in alkali, we decided to test the application of Eq. [1] to the data obtained with an in vivo-in vitro DNA unwinding assay for hepatic DNA damage caused by a monofunctional alkylating agent, DMN.

Data presented in Fig. 1 depict the kinetics of strand separation of hepatic DNA from control mice and from mice treated with 1.0 or $2.0 \mathrm{mg} / \mathrm{kg}$ of DMN. To obtain a value for $\beta$ in Eq. [1] (and to construct the abscissa in Fig. 1), a $\log -\log$ transformation of Eq. [1] was employed such that $\beta$ could be derived from a linear regression of the kinetic data using

$$
\log (-\ln F)=\log \left(C / M_{n}\right)+\beta \log t
$$

$\beta$ Values obtained in this manner were 0.62 for control DNA and 0.61 and 0.58 , respectively, for the DNA from animals treated with 1.0 and $2.0 \mathrm{mg} / \mathrm{kg}$ of DMN. The coefficient of determination was greater than 0.98 in each case, indicating a good fit of the data to Eq. [2]. A mean value for $\beta$ of 0.603 was therefore employed to construct the abscissa in Fig. 1. This value agrees quite well with

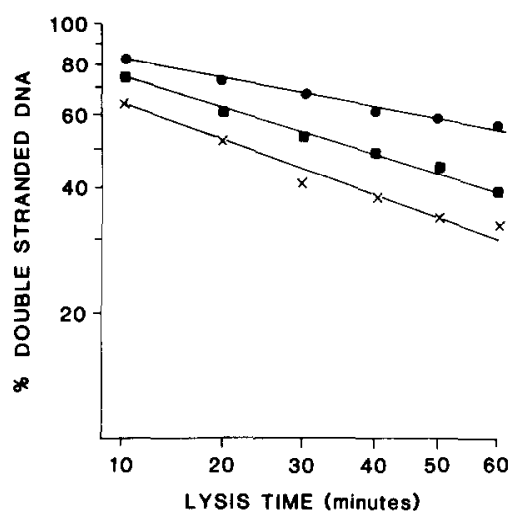

FIG. 1. Kinetics of DNA strand separation in alkali. $N$-Nitrosodimethylamine at doses of $1.0 \mathrm{mg} / \mathrm{kg} \mathrm{( \square )}$ and $2.0 \mathrm{mg} / \mathrm{kg}(X)$ or saline (e) was administered to one B6C3F1 male mouse/group. Mice were sacrificed $4 \mathrm{~h}$ later and the percentage of the hepatic DNA remaining double stranded after alkali treatment was determined in duplicate at 10-min intervals. The percentage of double-stranded DNA is given on the ordinate in logarithmic scale and the time of alkali treatment in minutes is given on the abscissa on a linear basis proportional to (time) ${ }^{\beta}$. A value of 0.603 was determined for $\beta$ as described in the text. (See Results.)

those determined previously by Rydberg [0.66, (18)], and by Kanter and Schwartz $[0.62,(19)]$. The model thus appears to adquately describe the kinetics of DNA strand separation after DNA damage by a monofunctional alkylating agent as well as after damage caused by ionizing radiation.

The sensitivity of the in vivo-in vitro alkaline DNA unwinding assay was investigated in separate experiments in which $0.25-2.5$ $\mathrm{mg} / \mathrm{kg}$ doses of DMN were administered to groups of three mice and hepatic DNA damage was measured $4 \mathrm{~h}$ later. Results presented in Table 1 indicate that the method is sensitive enough to detect a statistically significant decrease in the percentage of the total DNA recovered as double-stranded DNA after doses of DMN as low as $0.5 \mathrm{mg} / \mathrm{kg}$. The limit of sensitivity thus appears comparable to that obtained in similar experiments with rats using in vivo-in vitro alkaline elution (14), alkaline DNA unwinding (14), or unscheduled DNA synthesis (16) assays. Species differences in response to DMN between rats 
TABLE 1

HePatic DNA DAMAgE after IN VIVO ADMINISTRATION OF $N$-NitrosodimEThylamine ${ }^{a}$

\begin{tabular}{lccccc}
\hline Compound & $\begin{array}{c}\text { Dose } \\
(\mathrm{mg} / \mathrm{kg})\end{array}$ & $\begin{array}{c}\text { \% Double-stranded } \\
\text { DNA }\end{array}$ & \% Change & $n^{c}$ & $n^{b} \mathbf{m g} / \mathbf{k g}^{d}$ \\
\hline Saline & - & $62.5 \pm 3.9$ & - & - & - \\
DMN & 0.25 & $58.9 \pm 1.9$ & -3.6 & 0.13 & 0.52 \\
DMN & 0.5 & $55.1 \pm 1.6^{e}$ & -7.4 & 0.27 & 0.54 \\
DMN & 1.0 & $43.2 \pm 2.8^{e}$ & -19.3 & 0.79 & 0.79 \\
DMN & 2.5 & $36.4 \pm 2.5^{e}$ & -26.1 & 1.15 & 0.46 \\
& & & & & $x=0.58 \pm 0.15$ \\
\hline
\end{tabular}

a DMN or saline was administered ip to three male B6C3F1 mice per group. After $4 \mathrm{~h}$, the mice were sacrificed, the livers were removed, and the mean \pm SD percentage of hepatic DNA remaining double stranded after the 40 min alkaline denaturation was determined.

${ }^{h}$ Control minus treated.

${ }^{c} n$ is the number of strand breaks induced per unit DNA by the treatment (see Results).

${ }^{d} n / \mathrm{mg} / \mathrm{kg}$ is the number of breaks induced per unit DNA per $\mathrm{mg} / \mathrm{kg}$ dose of DMN administered.

e Significantly different from control, $p<0.05$, by one-way analysis of variance (22) with multiple comparisons by the Bonferroni method (23).

and mice may be significant, however, and comparisons of this nature may therefore be misleading.

Kanter and Schwartz (19) have shown that the number of unwinding points $(p)$ and breaks $(n)$ induced per alkaline unwinding unit of DNA may be calculated from Eq. [1] with data such as are presented in Table 1. The number of unwinding points $(p)$ is derived from Eq. [1]:

$$
\left(M_{n_{0}}\right)\left(\ln F_{0}\right)=-K t^{\beta}=\left(M_{n_{x}}\right)\left(\ln F_{x}\right)
$$

and

$$
p=M_{n 0} / M_{n_{x}}=\left(\ln F_{x}\right) /\left(\ln F_{0}\right),
$$

where the subscripts $x$ and 0 refer to treated and control samples, respectively. The number of break points $(n)$ induced per unit DNA is then

$$
n=p-1 \text {. }
$$

Values for $n$ and $n / \mathrm{mg} / \mathrm{kg}$ of DMN arc presented in Table 1. These data indicate that a $1 \mathrm{mg} / \mathrm{kg}$ dose of DMN induces a mean value of 0.58 breaks per alkaline unwinding unit of hepatic DNA $\left(M_{n_{0}}\right)$ from male B6C3F1 mice. In a previous study by Kanter and Schwartz (19), a mean value of 6.0 $\times 10^{-3}$ breaks/rad was determined for two mammalian cell lines exposed in vitro to 01200 rads of ionizing radiation. We can therefore estimate that a dose of $0.5 \mathrm{mg} / \mathrm{kg}$ of DMN, the limit of sensitivity in the in vivo-in vitro alkaline DNA unwinding assay reported herein, is approximately equivalent in effect to 50 rads of ionizing radiation delivered to cultured mammalian cells in vitro.

In subsequent experiments, these results obtained using the in vivo-in vitro alkaline DNA unwinding assay were compared with those from a similar alkaline sucrose density gradient centrifugation assay. Results presented in Fig. 2 indicate that changes in the sedimentation pattern of hepatic DNA in alkaline sucrose gradients are clearly visible after a dose of $1 \mathrm{mg} / \mathrm{kg}$ DMN. A dosedependent shift in molecular-weight distribution is evident as the dose of DMN is increased from 1 to $10 \mathrm{mg} / \mathrm{kg}$. In subsequent experiments, the time allowed for alkaline DNA unwinding on top of the gradient was extended from 30 to 40 min since the sensitivity of the assay appeared, in separate experiments, to be maximal with a 40-min lysis time. The results, presented in Table 2, indicate that a statistically significant decrease 


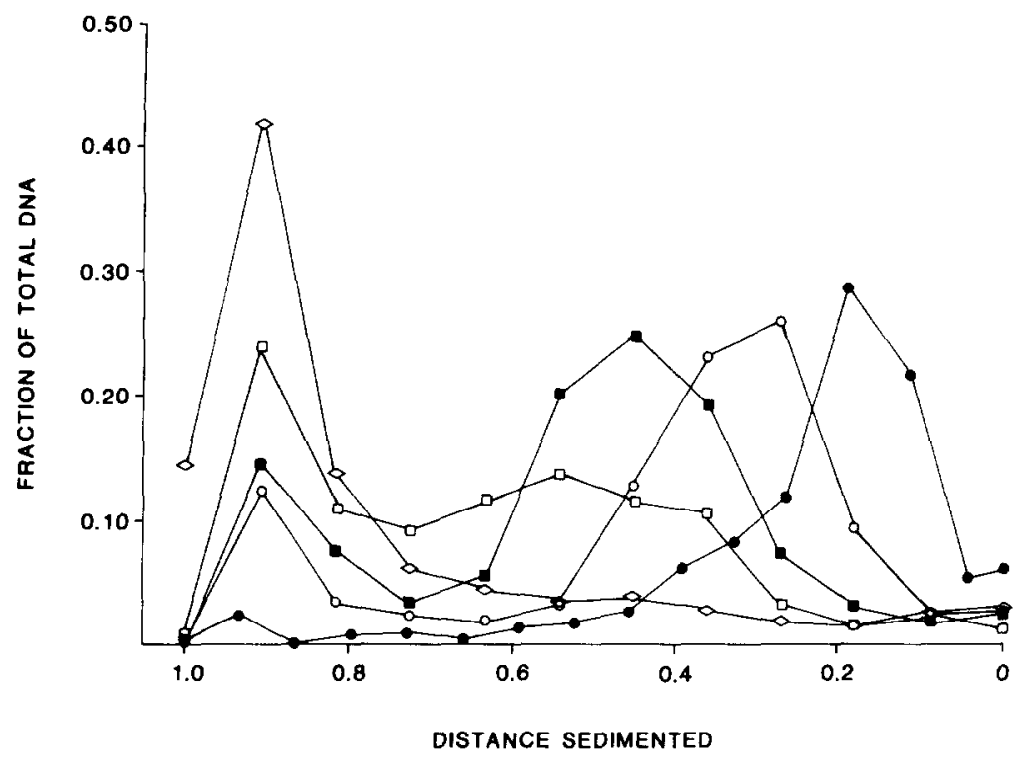

FIG. 2. Effect of DMN on the sedimentation pattern of hepatic DNA in alkaline sucrose gradients. DMN at doses of $1.0(\square), 2.5(\square), 5.0(O)$, and $10.0 \mathrm{mg} / \mathrm{kg}(\bullet)$, or saline $(\bigcirc)$ was administered ip in saline. Each curve represents the mean of two gradients from a single experiment. Similar patterns of results were obtained when experiments were repeated. The mean values for the percentage of the total DNA sedimenting in the bottom third of the gradients were 76.5 (saline), $44.0(1.0 \mathrm{mg} / \mathrm{kg}), 25.4(2.5 \mathrm{mg}$ ) $\mathrm{kg}), 18.1(5 \mathrm{mg} / \mathrm{kg})$, and $4.1(10 \mathrm{mg} / \mathrm{kg})$.

in the percent of the total DNA recovered in the bottom third of the gradient (fractions 1-4) can be detected after an $0.5 \mathrm{mg} / \mathrm{kg}$ dose of DMN. The magnitude of the effect is virtually identical to that seen at this dose level in the alkaline DNA unwinding assay.

Recently we have extended our investigations with these techniques to another class of genotoxic compounds, the 1,2-dihaloethanes $(27,28)$. A dose of $200 \mathrm{mg} / \mathrm{kg}$ DCE resulted in a $10.8 \%$ decrease in the percentage of the DNA recovered as double-stranded DNA in the alkaline unwinding assay (control, $59.4 \pm 8.1 \%$; treated, $48.6 \pm 4.9 \%$; six mice per group). With the alkaline sucrose gradient technique, the same dose of DCE

TABLE 2

Sedimentation Patterns of Hepatic dNa in Alkaline Sucrose Gradients after in VIVO ADMINISTRATION OF $N$-NITROSODIMETHYLAMINE ${ }^{a}$

\begin{tabular}{lcccc}
\hline & & \multicolumn{3}{c}{$\begin{array}{c}\text { Distribution of DNA in gradient fractions } \\
(\% \text { of total DNA })\end{array}$} \\
\cline { 3 - 4 } Compound & Dose & $1-4$ & $5-8$ & $9-12$ \\
\hline Control & - & $58.0 \pm 4.2$ & $26.8 \pm 0.8$ & $15.2 \pm 5.0$ \\
DMN & $0.5 \mathrm{mg} / \mathrm{kg}$ & $47.4 \pm 5.5^{b}$ & $38.3 \pm 7.4^{b}$ & $14.3 \pm 3.0$ \\
\hline
\end{tabular}

${ }^{a} \mathrm{DMN}$ or saline was administered ip to three (control) or four (treated) B6C3Fl male mice per group. After $4 \mathrm{~h}$ the mice were sacrificed, the livers were removed,and the hepatic DN $\wedge$ was analyzed for strand breaks by alkaline sucrose gradient centrifugation. A 40-min lysis period was employed.

${ }^{b}$ Significantly different from control, $p<0.05$, by one-way analysis of variance $(22)$. 
resulted in a $10.0 \%$ decrease in the percentage of the total DNA recovered in the bottom third (fractions 1-4) of the gradient (control, $56.9 \pm 5.4 \%$; treated, $46.9 \pm 13.1 \%$; four mice per group). Thus the limits of sensitivity were again very similar with both techniques.

\section{DISCUSSION}

In this communication we have shown that an alkaline DNA unwinding assay is an extremely sensitive technique for the detection of hepatic DNA damage in vivo. Statistically significant effects were seen after doses of DMN as low as $0.5 \mathrm{mg} / \mathrm{kg}$. The technique is quantitative and allows for the calculation of the number of strand breaks induced per alkaline DNA unwinding unit from a theoretical model equation for the kinetics of DNA strand separation. Using this model, and previously reported data for the efficiency of break production by ionizing radiation (19), we can estimate that the limit of sensitivity in this assay, $0.5 \mathrm{mg} / \mathrm{kg} \mathrm{DMN}$, is approximately equivalent in effect to 50 rads of ionizing radiation delivered to cultured cells in vitro. The method is also reproducible, and groups of four to six animals per dose level are usually sufficient to demonstrate a statistically significant effect at dose levels near the limit of sensitivity for the assay. The assay is straightforward and rapid. One person can analyze, in duplicate, samples of hepatic nuclei from 12-16 animals in 2-3 days.

An alkaline sucrose density gradient centrifugation assay (11) was the first in vivo-in vitro assay reported in the literature for the measurement of single-strand breaks and alkali-labile lesions in hepatic DNA. The in vivo-in vitro alkaline DNA unwinding assay reported here is adapted from this alkaline sucrose gradient technique. The techniques for isolation of hepatic nuclei and the conditions of alkaline denaturation and unwinding employed in the two assays are essentially the same. The only significant differences between the two techniques as reported in these studies are the volume of the alkaline lysis solution (or layer) used and the additional 30-40 min of alkaline treatment during ultracentrifugation of the hepatic DNA in the gradients. The former difference, in volume of lysis solution, would not be expected to be a significant difference between the two techniques since changes in the ratio of cell number to the volume of lysis solution has previously been shown to result in only very small differences in the extent of alkaline DNA unwinding (19). The significance of the 30-40 min alkaline exposure during ultracentrifugation is difficult to evaluate but, given the high viscosity of the alkaline sucrose solution, it seems doubtful that further changes in the percent of the total DNA unwound would occur during ultracentrifugation.

A comparison of the results obtained with the in vivo-in vitro alkaline DNA unwinding and alkaline sucrose gradient centrifugation assays revealed very similar limits of sensitivity and dose-response relationships for DMN, a potent carcinogen and alkylating agent, and for DCE. Whereas the conditions of nuclei isolation and of alkaline lysis and denaturation were essentially identical for both assays, the similarity in the results obtained is remarkable and suggests a common modus operandi for both techniques. Our findings, therefore, support the hypothesis that alkaline sucrose gradient techniques employing brief (30-40 min) periods for lysis and alkaline denaturation of DNA are, in effect, alkaline unwinding techniques which employ velocity sedimentation to release unwound segments of single-stranded DNA from a rapidly-sedimenting complex of incompletely denatured DNA $(7,17,25,26,29,30)$.

Pavlis et al. (26) have suggested that the size of the DNA (165S) released from anomalously sedimenting complexes of incompletely denatured DNA in alkaline sucrose gradients is dependent on shearing forces at the unwinding point. These authors proposed that unwinding of DNA in alkali is initiated at break points and proceeds until the un- 
wound single-strand segments become so large that shearing occurs at the unwinding point. DNA unwinding would then begin anew at the shearing point. According to this hypothesis DNA unwinding should proceed at a fairly uniform rate until the DNA is completely denatured. The model proposed for the kinetics of alkaline DNA unwinding (18) and the empirical data which appear to fit the model (18) indicate, however, that DNA unwinding at free ends is initially quite rapid but slows down with time as the rotation of the single-strand portions is increasingly impeded by viscous drag. Thus, the observed and predicted kinetics of alkaline DNA unwinding are not consistent with the idea that shearing occurs at unwinding points.

To reconcile these conflicting hypotheses, we propose that shearing of unwound, singlestrand segments of DNA at the unwinding point occurs as a result of vibration and/or acceleration forces only during the centrifugation of the DNA in alkaline sucrose gradients but not during the preceding 30-40 min period of alkaline DNA unwinding on top of the gradient. This is consistent with the observations of Kanter and Schwartz (19) that excess vibration of samples during alkaline DNA unwinding results in accelerated rates of denaturation. Since shear forces induced by vibration can create de novo breaks in intact DNA (18), it is logical to assume that the unwinding points for long segments of denatured, single-stranded DNA would be equally, if not more-, susceptible sites for shearing to occur. Thus, the frequently observed phenomenon of the release of approximately $165 \mathrm{~S}$ single-stranded DNA from anomalously sedimenting complexes of incompletely denatured DNA after alkaline sucrose gradient centrifugation might be explained by the action of shear forces occurring during ultracentrifugation on shear-susceptible sites, namely the alkaline DNA unwinding points. The liberation of these sheared segments from the complex might then be expected to occur by a mechanism similar to that proposed by Kohn (8) as the modus operandi for alkaline elution.
Other in vivo-in vitro methods for the detection of hepatic DNA damage which have proved useful in screening chemicals for carcinogenic potential and for investigating the organotropic effects of carcinogens include unscheduled DNA synthesis (UDS) $(15,16)$ and alkaline elution $(12,13,31)$. The in vivo-in vitro UDS assay (16) can detect a positive response in rats after doses of DMN as low as $0.1-1.0 \mathrm{mg} / \mathrm{kg}$, indicating that the method is very sensitive. Time requirements for the assay are substantial, however. The time required for isolating primary hepatocytes from each treated animal (30-60 min) limits the number of samples which can be run with each assay, and development of the autoradiographs takes approximately 2 weeks. The alkaline elution assay is also very sensitive, with a limit of detection for exposures of cultured cells to ionizing radiation of approximately 30 rads (32). Whereas the in vivo-in vitro version of the assay can employ crude nuclei preparations $(12,13)$, the number of samples that can be assayed is not as limited as it is for the UDS assay. A substantial investment in slow-speed peristaltic pumps and fraction collectors is required, however, to handle large sample sizes. The alkaline elution technique is also very versatile, in that protein-DNA crosslinks, DNADNA crosslinks, alkali-labile sites, and double-strand breaks can be measured with variations in the standard protocol for measuring single-strand breaks $(33,34)$.

In summary, the chief advantages of the in vivo-in vitro alkaline DNA unwinding technique described here are its sensitivity to low levels of hepatic DNA damage, the minimal time and equipment requirements for the assay, and the large number of samples that can be assayed concurrently. Recent improvements in methodology have increased the sensitivity of the in vitro unwinding assays to the point where the damage produced by as little as $1-10$ rads of ionizing radiation can be detected $(35,36)$. In addition, direct measurement of the fraction of the DNA that is double-stranded in neutralized lysates with fluorescent reagents can reduce the time 
requirement for the assay to 1 day $(36,37)$. Efforts to apply these improved techniques to the in vivo-in vitro assay described here are currently in progress in our laboratory and would further increase the utility of this assay. While this manuscript was in preparation, reports of two additional in vivo-in vitro alkaline DNA unwinding assays, for rat epidermis (38) and rat liver nuclei (14), have come to our attention. In the studies reported by Brambilla et al. (14), the in vitro alkaline DNA unwinding/hydroxylapatite batch chromatography assay described by Kanter and Schwartz (19) was used to analyze for single-strand breaks and alkali-labile lesions in hepatic DNA from rats treated with DMN or cimetidine and sodium nitrite. Thus, it appears that the alkaline DNA unwinding technique may find broader application in DNA damage studies, both in vivo and in vitro.

\section{REFERENCES}

1. Stich, H. F., and Kieser, D. (1974) Proc. Soc. Exp. Biol. Med. 145, 1339-1342.

2. San, R. H. C., and Stich, H. F. (1975) Int. J. Cancer 16, 284-291.

3. Williams, G. M. (1976) Cancer Lett. 1, 231-236.

4. Lett, J. T., Caldwell, I., Dean, C. J., and Alexander, P. (1967) Nature (London) 214, 790-792.

5. Sarma, D. S. R., Rajalakshmi, S., and Farber, E. (1975) in Cancer: A Comprehensive Treatise (Becker, F. F., ed.), Vol. 1, pp. 235-287, Plenum, New York.

6. Cleaver, J. E. (1975) in Methods in Cancer Research (Busch, H., ed.), Vol. 11, pp. 123-165, Academic Press, New York.

7. Ormerod, M. G. (1976) in Biology of Radiation Carcinogenesis (Yuhas, J. M., Tennant, R. W., and Regan, J. D., eds.), pp. 67-92, Raven Press, New York.

8. Kohn, K. W. (1979) in Methods in Cancer Research (Devita, V. T., and Busch, H., eds.), Vol. 16, pp. 291-345, Academic Press, New York.

9. Swenberg, J. A., and Petzold, G. L. (1979) in Strategies for Short-Term Testing for Mutagens/Carcinogens (Butterworth, B. E., ed.), pp. 77-86, CRC Press, West Palm Beach, Fla.

10. Sina, J. F., Bean, C. L., Dysart, G. R., Taylor, V. I., and Bradley, M. O. (1983) Mutat. Res. 113, 357391.

11. Cox, R., Damjanov, I., Abanobi, S. E., and Sarma, D. S. R. (1973) Cancer Res. 33, 2114-2121.

12. Petzold, G. L., and Swenberg, J. A. (1978) Cancer Res. 38, 1589-1594.

13. Parodi, S., Taningher, M., Santi, L., Cavanna, M.,
Sciaba, L., Maura, A., and Brambilla, G. (1978) Mutat. Res. 54, 39-46.

14. Brambilla, G., Cavanna, M., Maura, A., Pino, A., Robbiano, L., Carlo, P., Biassoni, F., and Ricci, R. (1982) J. Pharmacol. Exp. Ther. 221, 222227.

15. Craddock, V. M., and Henderson, A. R. (1978) Cancer Res. 38, 2135-2143.

16. Mirsalis, J. C., and Butterworth, B. E. (1980) Carcinogenesis, 1, 621-625.

17. Ahnstrom, G., and Erixon, K. (1973) Int. J. Radiat. Biol. Relat. Stud. Phys., Chem. Med. 23, 285289.

18. Rydberg, B. (1975) Radiat. Res. 61, 274-287.

19. Kanter, P. M., and Schwartz, H. S. (1979) Anal. Biochem. 97, 77-84.

20. Zubroff, J., and Sarma, D. S. R. (1976) Anal. Biochem. 70, 387-396.

21. Kissane, J. M., and Robbins, E. (1958) J. Biol. Chem. 233, 184-188.

22. Remington, R. D. and Schork, M. A. (1970) Statistics with Applications to the Biological and Health Sciences, Prentice Hall, Englewood Cliffs, N. J.

23. Neter, J., and Wasserman, W. (1974) Applied Linear Statistical Models, Richard D. Irwin, Inc., Homewood, III.

24. Shooter, K. V. (1976) Chem.-Biol. Interact. 13, 151163.

25. Heyting, C., Huigen, A., and Den Engelse, L. (1980) Carcinogenesis 1, 769-778.

26. Pavlis, R., Yatscoff, R. W., Sridhar, R., and Walker, I. G. (1978) Chem--Biol. Interact. 23, 31-44.

27. Storer, R. D., Bank, P. A., and Conolly, R. B. (1982) The Toxicologist 2, 129.

28. Storer, R. D., and Conolly, R. B. (1983) Carcinogenesis 4, 1491-1494.

29. Simpson, J. R., Nagle, W. A., Bick, M. D., and Belli, J. A. (1973) Proc. Natl. Acad. Sci. USA 70, 3660-3664.

30. Cleaver, J. E. (1974) Biochem. Biophys. Res. Commun. 59, 92-99.

31. Bermudez, E., Mirsalis, J. C., and Eales, H. C. (1982) Environ. Mutagen. 4, 667-680.

32. Kohn, K. W., Erickson, L. C., Ewig, R. A. G., and Friedman, C. A. (1976) Biochemistry 15, 46294637.

33. Kohn, K. W., Ewig, R. A. G., Erickson, L. C., and Zwelling, L. A. (1981) in DNA Repair: A Laboratory Manual of Research Procedures (Friedberg, E. C., and Hanawalt, P. C., eds.), pp. 379-401, Dekker, New York.

34. Bradley, M. O., and Kohn, K. W. (1979) Nucl. Acids Res. 7, 793-804.

35. Rydberg, B. (1980) Radiat. Res. 81, 492-495.

36. Birnboim, C., and Jevcak, J. J. (1981) Cancer Res. 41, 1889-1892.

37. Kanter, P. M., and Schwartz, H. S. (1982) Mol. Pharmacol. 22, 145-151.

38. Burns, F. J., and Sargent, E. V. (1981) Radiat. Res. 87, 137-144. 